Nataliya Tyukhtenko,

Dr.Sc., Professor, Kherson State University, Ukraine

(iD) ORCID ID, 0000-0003-4634-9139

email: tuhtenko1@gmail.com

Serhii Makarenko,

Ph.D, Associate Professor, Kherson State University, Ukraine

(iD) ORCID ID, 0000-0001-9929-8967

email: makar0684@gmail.com

Nataliia Oliinyk,

Ph.D, Associate Professor, Kherson National Technical University, Ukraine

(iD) ORCID ID, 0000-0002-1019-5708

email: nat-o@ukr.net

Edwin Portugal,

Ph.D, Professor, State University of New York in Potsdam, USA

Correspondence author: tuhtenko1@gmail.com

\title{
INNOVATIVE APPROACHES TO ENTERPRISE COMPETITIVENESS ASSESSMENT
}

Abstract. An important condition for the effective functioning of business entities of all forms of ownership in modern conditions of uncertainty and environment instability is the correct assessment of market conditions and opportunities in short- and long-term perspectives. The article aims to analyze modern methodological approaches to assess the competitiveness of enterprises to identify and justify possible aspects of their improvement taking into account the specifics of the functioning of domestic research objects. The research's methodology based on domestic and foreign scientific works, leading experts' opinions, statistical data and public authorities' analytical materials. The results were obtained by using expert methods - to investigate the impact of market factors and resource potential on light industry enterprises competitiveness; economic and mathematical methods - to calculate the integral indicator of the enterprise competitiveness; abstract-logic method - to theoretical generalization and formulation of conclusions. In determining the integral indicator of enterprise competitiveness, the method of taxonomic analysis was used with additional consideration of the specific weight of each factor influence on an integral indicator of enterprise competitiveness. In determining the specific impact of the indicators on the integrated indicator of the industrial enterprises' competitiveness, the external experts' views involved in the industry, their qualification competencies and the level of fluctuations in the middle of the study group were taken into account. It was revealed that the existence of an enterprise could be considered objectively justified if it produces goods needed from the public point of view and uses resources within the qualitatively and quantitatively defined by society. Therefore, it was proposed to allocate eight levels of competitiveness, considering the technological and resource armament to grade the light industry enterprises" competitiveness.

Keywords: management, innovation, competitiveness, integral indicator, evaluation

Introduction. An important condition for the effective functioning of business entities of all forms of ownership in modern conditions of uncertainty and instability of the environment is the correct estimation of market conditions and opportunities in short- and long-term prospects. An entity will not be able to achieve sustainable business success unless it continually investigates and analyses changes occurring in the markets for the final product and supply of raw materials, identifies and compare its capabilities with those of its closest competitors as a basis for developing a further prospective development plan.

Cite as: Tyukhtenko, N., Makarenko, S., Oliinyk, N., \& Portugal, E. (2021). Innovative Approaches to Enterprise Competitiveness Assessment. Marketing and Management of Innovations, 1, 278-289. http://doi.org/10.21272/mmi.2021.1-21

278 
Estimation of enterprise competitiveness level is needed to define priority effective and reasonable measures on the increase of efficiency of economic activity and competitiveness of products, works, services and enterprises in general; attraction of internal and external sources of financing introduce innovative technologies into the production process; program preparation seizure of new markets for raw materials supply and sales of final products, etc. The introduction of a mechanism for regular assessment of the company position in the relevant sectoral domestic and foreign markets using modern innovative methodological approaches will allow identifying possible problems in business activities at the initial stage, their consequences for the enterprise, which will allow developing and implementing an operational set of measures to neutralize them. This determined the relevance of the research topic, objective, and content.

The purpose of the article is to analyse modern methodological approaches to assess the competitiveness of enterprises, identify and justify possible aspects of their improvement considering the specific functioning of domestic research objects.

Literature Review. Competitiveness management requires an objective appraisal tool. Failure to choose the valuation method can lead to erroneous management decisions. At present, there is no generally accepted methodology for assessing the competitiveness of enterprises. Each company evaluates its competitive position by its methodology, and the essence and effectiveness of its application do not advertise.

Most methods of assessing the competitiveness of enterprises are based on the use of different ratios for the analysis of production activities, financial condition, the efficiency of the investments, etc. So, Taran V.A. (1998) for the main indicators of competitiveness of the enterprise proposes to accept: economic potential and efficiency of activity; level of management; production and marketing potentials, which reflect the ability of the enterprise to produce and sell certain products in the required quantities, in the required time; research potential; financial situation; the firm's reputation, its market strategy, innovative activity; state and qualification of labour resources. The technological development of enterprises as a separate subject of research has attracted the attention of practitioners who investigate relevant issues regarding national or international analytical generalizations (Ivanova et al., 2019). At the same time, the intensification of innovation development and the formation of a new economy based on technologies leads to the intensification of not only applied but also scientific research into the causes and consequences of changing the key technologies in a society, i.e. influencing the spread of technological know-how as well as the dynamics of consumer behaviour (Allen and Zook, 2001; Szilágyi, 2017). In a broader sense, technology is defined as the flow of specialized knowledge, processes and materials that are used in the design, production, and operation of products (Schumpeter, 2011; Zemlickiene et al., 2017). Research by Tsai and Wang $(2008,2009)$ on the reasons for an enterprise's technological development has determined connections with the evolution of the technology itself. The researchers have demonstrated the current need to replenish the tools of strategic analysis of the technological environment to choose promising new technologies to create or increase the competitive advantages of the enterprise.

At the same time, when assessing competitiveness, it is necessary to consider not only a set of indicators related to project management and agreements, but also other criteria - a set of conditions for the sale of products, after-sales services, utilization, the ability to supply production resources, limited availability of resources, etc. Unfortunately, in the work of Taran (1998), there are no specific indicators of competitiveness of the enterprise, and the method of calculating the integral indicator is not considered at all. Results of research of Schalminova (2000) devoid of the above disadvantages and to evaluate the competitiveness of the enterprise, the author proposes to choose a system of indicators of production efficiency, financial position, the efficiency of the organization of sales and promotion of goods, the competitiveness of goods and efficiency of the innovative project. Integral indicator of competitiveness Schalminova has obtained by the theory of desirability. The overall competitiveness of the enterprise is 
calculated as a geometric mean weighted average. This technique considers a large number of factors that ensure the competitive status of the enterprise. However, the method is not devoid of subjectivity, because the quantitative figure is initially subjectively translated into quality, and then on the "Harrington» scale again in the quantitative. Also, if one of the performance indicators of the Enterprise is zero (zero value of desirability), then the level of competitiveness will be zero, which may not be true. The accuracy of the assessment of competitiveness on this technique largely depends on the expert's qualifications and is largely subjective in the process because the integral indicator is calculated using leverage determined by experts. The same disadvantage is inherent in the integral indicator of competitiveness by Voronov (2000). The author believes that the competitiveness of the product and the enterprise that produces it is the same. Therefore, it does not consider the fact that the competitiveness of the goods is a determining factor of the competitiveness of the enterprise, but it is not exhaustive.

Zakharchenko (1999) conducts a comparative assessment of competitiveness in points on four groups of factors: production (quality, technical parameters, brand prestige, packaging, dimensions, level of repair service, universalism, reliability, service life, patent protection, etc.); price (price list, percentage discount on price, payment term, discount terms); distribution channels (direct delivery, sales offices, wholesale agents, agents and missionaries, dealers, market coverage, inventory control system, transportation system); promotion of products (advertising, individual sales, consumer incentives, demonstration trade, staff training, product information in the media). The author proposes to judge the prospect of increasing the competitiveness of the enterprise by the indicator of profitability or profitability of production. In cases where the profitability of production exceeds the average industry level, Zakharchenko (1999) believes that it is possible to speak of high efficiency of production or profit. This result, according to the author, indicates the availability of reserves for improving the competitiveness of the enterprise, since it is possible to reduce the price of products sold while increasing sales and increasing the amount of absolute profit. However, the author does not consider that with a decrease in the price of products the income of the enterprise increases only if the demand for the products is elastic. It should also be borne in mind that the profit of the enterprise in certain periods may increase due to circumstances independent of the measures taken by the management of the enterprise, for example, due to reduced tax burden, the level of profitability of production may increase, etc. However, this does not suggest a general increase level of competitiveness of the enterprise in the relevant domestic market segment.

Studies of competitiveness assessment techniques show that the interpretation of competitiveness criteria among scientists is ambiguous; the criteria may vary depending about study; the choice of criteria depends on the availability and openness of information about the research object.

Much more research is being done based on the identification of competitiveness factors. The key factor that determines the specifics of the methodological approach to assessing the level of competitiveness of the enterprise is the features of the internal and external business environment, in which the management of the company must decide on the optimization of quantitative and qualitative indicators of economic activity.

The system of indicators for each enterprise in a particular industry is different because each type of economic activity has its own characteristics, and therefore you can compare only those parameters that are identical in value and operate in the same market.

Consumers should only use quantitative and qualitative metrics that allow them to be evaluated objectively. In turn, the experts evaluate the competitiveness of the company on indicators that can be compared with similar indicators of competitors. When conducting an assessment in comparison with the main competitors, it is recommended to group the main technical and economic indicators according to the directions and characteristics of the activity (financial, production, marketing, etc.).

The analysis of each indicator makes it possible to conclude that in the same industry the enterprises may have virtually the same characteristics, but the volume of sales may differ significantly, and therefore 
the amount of profit and profitability indicators will differ. This indicates the need for additional research in all areas and across all aspects of economic activity to determine the impact of different groups of indicators on the competitiveness of the enterprise and timely development and implementation of a set of measures to neutralize their negative impact.

Methodology and research methods. The methodological basis of the research was made by the scientific works of domestic, foreign scientists and leading experts, statistical and analytical materials of public authorities. As a method of data collection for the research, the questionnaire was chosen. The survey was conducted among top executives of higher education institutions (Kherson State University, Kherson National Technical University), local state executive bodies (Department of Economic and Regional Development of Kherson Regional State Administration; Department of Investment and Industrial Policy of Kherson Regional State Administration), Kherson regional organization of trade union of workers of textile and light industry. The results were obtained by using the methods as follows: the expert opinionto study the impact of market factors and resource potential on the competitiveness of light industry enterprises; economic and mathematical - when calculating the integral indicator of enterprise competitiveness; abstract-logical - for theoretical generalization and formulation of conclusions.

In determining the integral indicator of enterprise competitiveness, the method of taxonomic analysis was used, with additional consideration of the specific impact of each factor on the integral indicator of enterprise competitiveness. This method is to perform the calculation of the integral evaluation in several stages:

Stage 1 - formation of the system of information space of evaluation - matrix of initial data $X=\left(x_{i j}\right)$.

Stage 2 - formation of a matrix of standardized values of attributes by changing the matrix $X$ to the matrix $Z$. The elements of the matrix $Z$ are calculated by the formula:

$z_{i j}=\frac{x_{i j}-x_{a v . j}}{\delta_{j}}$

where $x_{a v . j}$ - the average value of the j-th indicator; $\delta_{j}-$ rms deviation of $\mathrm{j}$-th index.

Stage 3 - formation of «point-standard» with coordinates $Z_{01}, Z_{02}, \ldots, Z_{0 n}$.

Stage 4 - Euclidean distance $\left(\mathrm{C}_{\mathrm{i}}\right)$ calculation by the formula:

$C_{i 0}=\sqrt{P_{j} \times \sum_{j=1}^{n}\left(Z_{i j}-Z_{0 j}\right)^{2}}$

where $P_{j}$ the share of the impact of the $j$-th indicator on the enterprise competitiveness index.

The distances obtained are the initial values used in the calculation of the integral index.

Stage 5 - calculation of values of integral index $\left(\mathrm{d}_{\mathrm{i}}\right)$ using the formulas:

$d_{i}=1-\frac{C_{i 0}}{C_{0}}$

where

$C_{0}=C_{a v .0}+2 \times S_{0}$

$C_{a v .0}=\frac{1}{m} \times \sum_{i=1}^{m} C_{i 0}$ 


$$
S_{0}=\sqrt{\frac{1}{m} \sum_{i=1}^{m}\left(C_{i 0}-C_{a v .0}\right)^{2}}
$$

The proposed methodology can be used both for the overall evaluation of the efficiency of the enterprise and the competitiveness of the enterprise and for the evaluation of its component of functioning.

In determining the specific impact of the j-th indicator on the integral indicator of the competitiveness of industrial enterprises, a survey was conducted among certain institutions of higher education, local government bodies and trade union organizations. Given that each of the experts involved in the survey has a different level of qualifications, it was suggested to use the developed by the authors (Tyukhtenko and Makarenko, 2016; Makarenko et al., 2018) methodological approaches with additional consideration of the level of fluctuations of the corresponding qualification competences in the middle of the study group.

Expert competence was calculated using the following formula:

$$
K_{a v . j}=\frac{K_{1}+K_{2}+\cdots+K_{n}}{n}
$$

where $\mathrm{K}$ is the coefficient of experts' competence; $K_{1}$ - coefficient, which is assigned depending on the available level of education, scientific degree, academic rank; $K_{2}-a$ coefficient that is assigned depending on the overall experience of the profile; $K_{3}-$ a coefficient that is assigned based on industry experience; $\mathrm{K}_{4}$ - is a coefficient that is assigned depending on the $\mathrm{n}$-factor; $\mathrm{n}$ - the number of factors by which the level of expertise is assessed.

To translate the qualitative components that characterize the level of education of experts, it is suggested to use the following scale of assessment in quantitative indicators: persons with the lowest degree of higher education «junior bachelor» - get 1 point. For all other individuals, their grade points will increase depending on the interval of study. That is: for persons who have a bachelor's degree -2 points, a master's degree -4 points, a scientific degree "Candidate of Sciences (Doctor of Philosophy)» -7 points, «Doctor of Sciences» -9 points. For individuals with two or more undergraduate degrees, they are postgraduate or doctoral students - plus one additional point for each component.

The following formula was used to translate a particular set of indicators with different units of measurement into a single scale of evaluation:

$$
\sum K_{j}=\sum_{i=1}^{n} \frac{x_{\max }-x_{i j}}{x_{\max }-x_{\min }}+\sum_{i=1}^{n} \frac{x_{i j}-x_{\min }}{x_{\max }-x_{\min }}
$$

where $K_{j}$ - the coefficient of competence of the j-th expert for each of the indicators characterizing a particular component of activity; $X_{i j}$ - the value of the $i$-th indicator of the $j$-th expert $X_{\max }$ - the maximum value of the $i$-th indicator in the middle of the study expert group; $X_{\min }$ - the minimum value of the $i$-th indicator in the middle of the examined expert group.

The first part of the formula is used to evaluate indicators whose growth has a positive impact on the level of competence of the experts involved (education, work experience, etc.), the second part - to evaluate indicators whose increase has a negative effect (number of industrial conflicts, number of absences to work, etc.).

The best and most competent is the expert whose arithmetic mean of the sum of the ratings is the lowest. To determine the proportion of impact and the level of competence of the group experts in assessing the competitiveness of enterprises, it is necessary to translate the results obtained using the following formula: 


$$
K_{k_{j}}=\frac{1}{K_{a v \cdot j}}
$$

where $K_{K_{j}}$ - the point coefficient of competence of the j-th expert.

Given that all groups of indicators are important in assessing the level of competitiveness of enterprises, the created expert group should determine the specific weight of the impact of each factor on the overall performance indicator - in this case, the enterprise competitiveness index. As an example, you can suggest using their ranking of each expert from larger to smaller as follows:

Expert \# 1: Factor $1>$ Factor $2=$ Factor $3>$ Factor $4=\ldots>$ Factor $n$
Expert \# 2: Factor $4>$ Factor $3=$ Factor $1>$ Factor $2=\ldots>$ Factor $n$
Expert \# m: Factor $3>$ Factor $4=$ Factor $2>$ Factor $1=\ldots>$ Factor $n$

Considering that in the current conditions of limited production resources and the constant growth of consumer demand for purchased products, works performed and services rendered, only an enterprise that will provide quality production of products, works, provision of services with optimal consumption of available production resources can hope for prosperity, then the conditions of competitive technological and resource arms of production processes can be reflected as follows:

$$
\left\{\sum_{i=1}^{n} M P F \rightarrow 0_{C / c \rightarrow \min }^{\Pi_{F} \geq \Pi_{n}}\right.
$$

where $\pi_{f}$ and $\pi_{n}$-respectively actual and regulatory (industry) profit; MPF is the marginal productivity of factors of production $\mathrm{S} / \mathrm{C}$ - Cost of production (works, services); $\mathrm{C} / \mathrm{C}$ - the cost of production (works, services).

Results. In today's conditions of intense competition, the success of the enterprise in the domestic and foreign markets for the sale of final products depends on an organized system of formation and enhancement of competitiveness, which is the main link that provides high efficiency of its economic activity. Achieving strategic goals is to some extent hindered by the lack of the necessary theoretical developments and practical testing of an effective innovation model to assess the competitiveness of the enterprise as a basis for timely identification of emerging problems and implementation of appropriate preventive measures. For choosing the optimal plan of measures for improving the competitiveness of the enterprise, it is necessary to ensure the calculation of the integral indicator of the competitiveness of the enterprise and to examine the specifics of its changes in recent years. At the same time, it should be borne in mind that the use of a wide range of indicators in assessing the level of competitiveness can lead to a reduction in the proportion of the most influential factors, increase the likelihood of error in forecasting, and direct the enterprise management to implement another set of measures to improve the values that are not relevant to the enterprise.

Given the above, a working group with leading experts was created to determine the most important factors influencing the competitiveness of the enterprise. Using formulas 7-9, Table 1 shows the results of calculating the competence score and the specific gravity of each expert involved.

Table 2 shows the results of the survey conducted by the experts of the established working group on the importance of certain indicators (staff productivity, A1; return on assets, A2; staff turnover ratio, A3; profitability of realized products by gross profit, $A 4$; current liquidity ratio, $A 5$; share of export in total sales volume, A6; specific gravity of the company's products in the domestic market, A7) on the competitiveness of the enterprise. 
Table 1. Calculation of the point coefficient of competence and specific gravity of influence of each of the experts involved

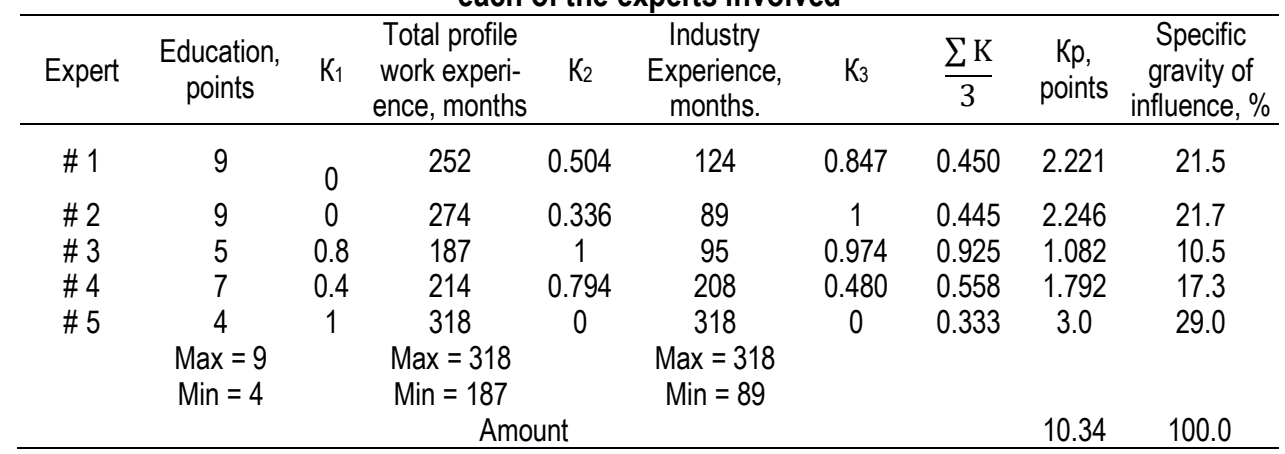

Sources: developed by the authors.

Table 2. Results of the expert survey on the weight of the indicators identified

\begin{tabular}{cc}
\hline EXPERT & THE IMPORTANCE OF METRIC GROUPS \\
\hline$\# 1$ & $A_{1}=A_{3}>A_{4}>A_{7}=A_{6}>A_{5}>A_{2}$ \\
$\# 2$ & $A_{3}>A_{1}>A_{4}>A_{6}>A_{7}>A_{5}>A_{2}$ \\
$\# 3$ & $A_{6}>A_{7}>A_{5}>A_{1}=A_{3}>A_{4}>A_{2}$ \\
$\# 4$ & $A_{4}>A_{6}=A_{7}>A_{1}=A_{3}>A_{5}>A_{2}$ \\
$\# 5$ & $A_{1}=A_{3}>A_{4}>A_{6}=A_{7}>A_{5}>A_{2}$ \\
\hline
\end{tabular}

Sources: developed by the authors.

In determining the specific impact of each indicator on the resulting factor (enterprise competitiveness index), it is proposed to use the following system of calculations: first place in the rating -7 points, second -6 points, third -5 points, fourth -4 points, fifth -3 points, sixth -2 points, seventh (last) -1 point. The total amount is 28 points. Table 3 shows the results of the calculation of the weighting coefficients of indicators, considering the specific gravity of the impact of experts. Using the results obtained for the weighted coefficients of the proposed indicators, formulas 1-6 and methodical approach to assessing the competitiveness of the enterprise based on taxonomic analysis, the competitiveness index of LLC «Amalteya» in 2014-2018 was calculated.

Table 3. Calculation of weights of the proposed indicators

\begin{tabular}{ccc}
\hline Indicator & Grade score taking into account competence factor & Weight ratio \\
\hline A1 & $6.5^{*} 0.215+6^{*} 0.217+3.5^{*} 0.105+3.5^{*} 0.173+6.5^{*} 0.29=5.6$ & 0.198 \\
A2 & $1^{*} 0.215+1^{*} 0.217+1^{*} 0.105+1^{*} 0.173+1^{*} 0.29=1.0$ & 0.036 \\
A3 & $6.5^{*} 0.215+7^{*} 0.217+3.5^{*} 0.105+3.5^{*} 0.173+6.5^{*} 0.29=5.8$ & 0.206 \\
A4 & $5^{\star} 0.215+5^{*} 0.217+2^{*} 0.105+7^{*} 0.173+5^{*} 0.29=5.0$ & 0.18 \\
A5 & $2^{*} 0.215+2^{*} 0.217+5^{*} 0.105+2^{*} 0.173+2^{*} 0.29=2.3$ & 0.083 \\
A6 & $3.5^{*} 0.215+4^{*} 0.217+7^{*} 0.105+5.5^{*} 0.173+3.5^{*} 0.29=4.3$ & 0.154 \\
A7 & $3.5^{*} 0.215+3^{*} 0.217+6^{*} 0.105+5.5^{*} 0.173+3.5^{*} 0.29=4.0$ & 0.143 \\
Amount & 28 & 1.0 \\
\hline
\end{tabular}

Sources: developed by the authors.

Table 4 presents a generalized system of information space for the calculation of the integral indicator of the competitiveness level of LLC «Amalteya». 
N., Tyukhtenko, S., Makarenko, N., Oliinyk, E., Portugal. Innovative Approaches to Enterprise Competitiveness Assessment

Table 4. Information space system for calculating the integral indicator of the enterprise competitiveness assessment

\begin{tabular}{ccccccc}
\hline \multirow{2}{*}{ Code } & Indicator & \multicolumn{5}{c}{ Years } \\
\cline { 3 - 7 } & & 2014 & 2015 & 2016 & 2017 & 2018 \\
\hline A1 & Staff productivity, thousand units/person & 103.5 & 101.8 & 102.0 & 102.2 & 103.9 \\
A2 & Return on assets & 1.03 & 0.9 & 0.91 & 0.92 & 0.95 \\
A3 & Staff turnover ratio & 0.05 & 0.214 & 0.189 & 0.103 & 0.159 \\
A4 & Profitability of realized products by gross profit, $\%$ & 4.1 & 3.95 & 3.9 & 4.0 & 4.2 \\
A5 & Current liquidity ratio & 1.6847 & 2.0176 & 1.9088 & 2.3435 & 1.7405 \\
A6 & Export share in total sales volume, \% & 20 & 14 & 16 & 17 & 19 \\
A7 & Specific gravity of the company's products in the & 19 & 17 & 16 & 15 & 16 \\
\hline
\end{tabular}

Sources: developed by the authors.

Table 5 shows the calculation of the mean value and standard deviation for the group of indicators characterizing the level of competitiveness of LLC «Amalteya».

Table 5. Calculation of mean and standard deviation

\begin{tabular}{|c|c|c|c|c|c|c|c|}
\hline \multirow{2}{*}{ Indicators } & \multicolumn{5}{|c|}{ Years } & \multirow{2}{*}{ A } & \multirow[b]{2}{*}{$\sigma$} \\
\hline & 2014 & 2015 & 2016 & 2017 & 2018 & & \\
\hline $\mathrm{A} 1$ & 103.5 & 101.8 & 102.0 & 102.2 & 103.9 & 102.68 & 0.852 \\
\hline $\mathrm{A} 2$ & 1.03 & 0.9 & 0.91 & 0.92 & 0.95 & 0.94 & 0.047 \\
\hline A3 & 0.05 & 0.214 & 0.189 & 0.103 & 0.159 & 0.14 & 0.059 \\
\hline A4 & 4.1 & 3.95 & 3.9 & 4.0 & 4.2 & 4.03 & 0.108 \\
\hline A5 & 1.6847 & 2.0176 & 1.9088 & 2.3435 & 1.7405 & 1.94 & 0.234 \\
\hline A6 & 20 & 14 & 16 & 17 & 19 & 17.20 & 2.135 \\
\hline A7 & 19 & 17 & 16 & 15 & 16 & 16.60 & 1.356 \\
\hline
\end{tabular}

Sources: developed by the authors.

Table 6 shows standardized values of indicators, intermediate values of point-standard, Euclidean distance and integral indicator.

Table 6. Standardized values of indicators, intermediate values of point-standard, Euclidean distance and integral index

\begin{tabular}{|c|c|c|c|c|c|c|c|c|c|c|}
\hline \multirow{2}{*}{ Indicators } & \multirow{2}{*}{$\begin{array}{l}\text { Weight } \\
\text { ratio }\end{array}$} & \multicolumn{5}{|c|}{ Years } & \multirow{2}{*}{$\begin{array}{l}\text { Point of } \\
\text { reference }\end{array}$} & \multirow{2}{*}{$\overline{C_{0}}$} & \multirow[b]{2}{*}{$\mathrm{S}_{0}$} & \multirow{2}{*}{$C_{0}$} \\
\hline & & 2014 & 2015 & 2016 & 2017 & 2018 & & & & \\
\hline $\mathrm{A} 1$ & 0.198 & 0.963 & -1.033 & -0.798 & -0.563 & 1.432 & 1.432 & & & \\
\hline $\mathrm{A} 2$ & 0.036 & 1.869 & -0.892 & -0.680 & -0.467 & 0.170 & 1.869 & & & \\
\hline A3 & 0.206 & -1.565 & 1.195 & 0.774 & -0.673 & 0.269 & -1.565 & & & \\
\hline A4 & 0.18 & 0.650 & -0.743 & -1.207 & -0.279 & 1.578 & 1.578 & & & \\
\hline A5 & 0.083 & -1.085 & 0.335 & -0.129 & 1.725 & -0.847 & 1.725 & & & \\
\hline A6 & 0.154 & 1.311 & -1.499 & -0.562 & -0.094 & 0.843 & 1.311 & & & \\
\hline A7 & 0.143 & 1.769 & 0.295 & -0.442 & -1.180 & -0.442 & 1.769 & & & \\
\hline $\begin{array}{c}\text { Euclidean distance } \\
\text { Competitive }\end{array}$ & & 0.924 & 2.388 & 2.295 & 1.821 & 1.442 & & 1.774 & 0.545 & 2.863 \\
\hline $\begin{array}{c}\text { Capacity Integral } \\
\text { indicator }\end{array}$ & & 0.68 & 0.17 & 0.20 & 0.36 & 0.50 & & & & \\
\hline
\end{tabular}

Sources: developed by the authors. 
The results of the calculation of the integral index of competitiveness of the enterprise obtained in Table 6 show that the efficiency and competitiveness of the investigated object during 2015-2017 significantly decreased compared to the indicator of 2014. Since 2015, there has been a significant decrease in the main indicators of the enterprise's economic activity, which is directly related to the loss of raw materials supply and sales markets due to the annexation of the Autonomous Republic of Crimea and military conflicts in the east of Ukraine. Also, the introduction of a visa-free regime with EU countries was negatively affected by the efficiency of staff involvement in the production process, which led to an increase in the staff turnover rate. At the same time, because of the implementation of the topmanagement of LLC «Amalteya» operational measures to maximize productivity, expansion of distribution channels and the seizure of free-market segments in both domestic and international markets, the integral indicator of the competitiveness of the enterprise has begun to grow significantly and the operational information already in the results of 2019 exceeded the figure of 2014. To achieve long-term success, the work to ensure enterprise competitiveness should be implemented in all spheres and all aspects of economic activity. The conducted research (Tyukhtenko et al., 2018) show that when calculating the level of competitiveness of light industry enterprises, it is necessary to take into account the factors that determine the level of:

- reliability of the information on markets for finished goods and production resources. Without the means of collection and processing, the information system cannot see the problem itself, assess the level of competitiveness, and therefore cannot ensure the development and implementation of adequate preventive actions. It should also be borne in mind that having false information can create an even worse situation because the resources you need can be used inefficiently and directed to improve other, nonessential factors;

- without the resources available to the existing technology, it is impossible to organize the appropriate response and, conversely, some resources are always in the system, but needed technology is not always available;

- adaptability to changing external conditions of the enterprise organizational system (availability of sufficient time to organize the appropriate response). Without time, even in the presence of information and sufficient functional weaponry of the system, it is not possible to implement an effective set of measures promptly to eliminate the relevant threats.

Table 7 shows the proposals for the graduation of the level of competitiveness of industrial enterprises, taking into account marginal costs of factors of production (ME), marginal revenue (MR), the marginal productivity of factors of production (MPF), selling prices ( $\mathrm{P})$, actual ( $\mathrm{m}$ ) and regulatory (mid-industry) ) $(\pi n)$ profit, average total (ATC), and fixed costs (AFC).

Table 7. Proposals for the graduation of the level of competitiveness of enterprises, taking into account technological and resource weaponry

\begin{tabular}{|c|c|c|}
\hline Competitiveness level & Calculation formula & Characteristic \\
\hline Higher-level & $\begin{aligned} \mathrm{ME} & =\mathrm{MR}{ }^{*} \mathrm{MPF} \\
\mathrm{P} & =\mathrm{ATC}+\mathrm{mf}\end{aligned}$ & The enterprise is completely safe \\
\hline First level & $\begin{aligned} M E & >M R * M P F \\
P & =A T C+\pi f\end{aligned}$ & $\begin{array}{l}\text { Businesses may have problems in the future as fast as } \\
\text { the greater the excess of cost over the objectively needed }\end{array}$ \\
\hline $\begin{array}{l}\text { Second level (unstable } \\
\text { equilibrium) }\end{array}$ & $\begin{aligned} M E & =M R * M P F \\
P & =A T C+\pi n\end{aligned}$ & $\begin{array}{c}\text { The enterprise is in an unstable security state, as minor } \\
\text { changes to external or internal links will lead to the } \\
\text { actualization of threats }\end{array}$ \\
\hline Third level (hazard actualization) & $\begin{array}{l}\text { ME }>\text { MR * MPF; } \\
P=A T C+\pi n\end{array}$ & $\begin{array}{l}\text { The enterprise may face challenges that pose a real threat } \\
\text { to its existence }\end{array}$ \\
\hline Fourth level (Survival stage) & $\begin{array}{l}M E=M R{ }^{*} M P F \\
\quad P=A T C\end{array}$ & $\begin{array}{l}\text { The enterprise does not profit but has the opportunity to } \\
\text { recover soon }\end{array}$ \\
\hline
\end{tabular}




\begin{tabular}{|c|c|c|}
\hline Fifth Level (Extinction Level) & $\begin{array}{l}\mathrm{ME}>\mathrm{MR} \text { * MPF; } \\
P=A T C\end{array}$ & The enterprise tends to reduce production \\
\hline Level six (Bankruptcy) & $\begin{array}{l}M E=M R{ }^{*} M P F \\
P=A T C-A F C\end{array}$ & $\begin{array}{c}\text { The company is in the bankruptcy stage, but remediation } \\
\text { is possible }\end{array}$ \\
\hline Level seven & $\begin{array}{l}M E>M R * M P F \\
P=A T C-A F C\end{array}$ & Self-liquidation takes place \\
\hline
\end{tabular}

Sources: developed by the authors.

The use of the proposed method of graduation will allow to determine the level of competitiveness of industrial enterprises and to outline the necessary set of priority actions for improving the efficiency of economic activity.

Conclusions. The conducted research testifies that the estimation of competitiveness of the enterprise is a difficult multifactorial task which is reduced to identification of the most significant numerical indicators of competitiveness and their integration. Most methods for assessing the competitiveness of enterprises based on the application of different coefficients for the analysis of production activities, financial status, the efficiency of capital investments, etc. Many authors in the role of estimation indicators choose financial indicators. However, in practice, there are quite often cases where businesses with completely normal financial performance are on the verge of bankruptcy and liquidation. Therefore, not only the indicators used in the assessment of competitiveness should reflect information on the efficiency of use of internal economic growth resources and functional aspects of the enterprise, but also the proposed methodological approach should consider the current conditions of the entity in the relevant market segment. It is revealed that the implementation of measures to ensure the competitiveness of enterprises should be carried out in all spheres and all aspects of their activities. The important condition for the survival of the company in the uncertainty of the market environment is the correct assessment of all market conditions and opportunities of the enterprise. The purpose of the assessment is to determine the position of the company in the sectoral domestic and foreign markets. Achieving this goal is only possible if there is an operational and objective methodology for assessing competitiveness. In determining the integral index of enterprise competitiveness, it was proposed to use the taxonomic analysis method with additional consideration of the specific impact of each factor on the integral indicator of enterprise competitiveness. In determining the specific impact of the indicators on the integrated indicator of the competitiveness of industrial enterprises, the views of external experts involved in the industry and their qualification competencies were considered, as well as the level of fluctuations in the middle of the study group. The results of the calculation of the integral index of competitiveness of the studied enterprise show that the efficiency and competitiveness of the investigated object during 20152017 significantly decreased compared to the indicator of 2014. Since 2015, there has been a significant decrease in the main indicators of the enterprise's economic activity, which is directly related to the loss of raw materials supply and sales markets due to the annexation of the Autonomous Republic of Crimea and military conflicts in the east of Ukraine. Also, the introduction of a visa-free regime with EU countries was negatively affected by the efficiency of staff involvement in the production process, which led to an increase in the staff turnover rate. At the same time, because of the implementation of the topmanagement the enterprise, operational measures to maximize productivity, expansion of distribution channels and the seizure of free-market segments in both domestic and international markets, the integral indicator of the competitiveness of the enterprise has begun to grow significantly and the operational information already in the results of 2019 exceeded the figure of 2014

It is revealed that the existence of an enterprise can be considered objectively justified if it produces goods needed from the public point of view and uses resources within the qualitatively and quantitatively defined by society. Based on the, it was proposed to allocate eight levels of competitiveness, taking into 
account technological and resource armament, when grading the competitiveness of light industry enterprises. The mechanism for determining the coefficient of competence of experts involved in assessing the competitiveness of the enterprise, considering their qualitative and quantitative characteristics, deserves further study. That would maximize the effectiveness of the rating assessment and coordinate efforts and resources to improve the indicators identified and relevant to the enterprise.

Author Contributions: conceptualization, N. T.; methodology, S. M.; software, S. M.; validation, N. T. and N. O.; formal analysis, N. O.; investigation, S. M.; resources, S.R., Ya. O.; data curation, S. R., Ya. O.; writing-original draft preparation, S. M.; writing-review and editing, N. T. and S. R.; visualization, S. M.; supervision, N. O.; project administration, N. T.; funding acquisition, S. R.

Funding. This research was supported by the Kherson regional organization of the trade union of textile and light industry workers and the primary trade union organization of «Kherson Cotton Factory».

\section{References}

Allen, J., \& Zook, C. (2001). Profit from the core: a return to growth in turbulent times. Harvard Business School Press: Bain \& company, Inc. [Google Scholar]

Ivanova, A. S., Holionko, N. G., Tverdushka, T. B., Olejarz, T., \& Yakymchuk, A. Y. (2019). The Strategic Management in Terms of an Enterprise's Technological Development. Journal of Competitiveness, 11(4), 40. [Google Scholar] [CrossRef].

Makarenko, S., Oliinyk, N., \& Kazakova, T. (2018). Improving the method approach to the rating evaluation of employees as professional career development. Baltic Journal of Economic Studies, 4(5), 179-187. [Google Scholar] [CrossRef]

Schalminova, A. S. (2000). Innovative business planning for the development of the priority industry: autoref. Thesis PhD in Economics. Kazan.

Schumpeter, J. (2011). Theory of Economic Development: An Inquiry into Profits, Capital, Credit, Interest, and the Business Cycle. Kyiv: Publishing House of «Kyiv-Mohyla Academy».

Szilágyi, G. A. (2017). Exploration Knowledge Sharing Networks Using Social Network Analysis Methods. Economics and Sociology, 10 (3), 179-191. https://doi.org/10.14254/2071-789X.2017/10-3/13.

Taran, V.A. (1998). Competitiveness of enterprises: problems of modern policy and strategy in the field of quality. Machine builder , 2, 6-12. [Google Scholar]

Tsai, K. H., \& Wang, J. C. (2008). External technology acquisition and firm performance: A longitudinal study. Journal of Business Venturing, 23(1), 91-112. [Google Scholar] [CrossRef]

Tsai, K. H., \& Wang, J. C. (2009). External technology sourcing and innovation performance in LMT sectors: An analysis based on the Taiwanese Technological Innovation Survey. Research Policy, 38(3), 518-526. [Google Scholar] [CrossRef]

Tyukhtenko, N. A., \& Makarenko, S. M. (2016). Economic and mathematic models for staff planning at enterprises of all ownership forms. Actual problems of economics, 1(175), 435-442. [Google Scholar]

Tyukhtenko, N. A., Makarenko, S. M., \& Oliinyk, N. M. (2018). Increasing competitiveness of the enterprise by improving logistic strategy of distribution of production and supply of raw materials. Scientific bulletin of Polissia, 2(2 (14)), 56-63. [Google Scholar]

Voronov, A. A. (2000). To the assessment of the competitiveness of engineering enterprises. Machine builder, 12, 27-29.

Zakharchenko V.I. (1999). Assessment and analysis of the competitiveness of enterprises. Machine builder, 11, 13-17.

Zemlickiene, V., Mačiulis, A., \& Tvaronavičiene, M. (2017). Factors impacting the commercial potential of technologies: expert approach. Technological and Economic Development of Economy, 23(2), 410-427. [Google Scholar] [CrossRef]

Наталія Тюхтенко, д.е.н., професор, Херсонський державний університет, Україна

Сергій Макаренко, к.е.н., доцент, Херсонський державний університет, Україна

Наталія Олійник, доцент, Херсонський національний технічний університет, Україна

Едвін Португал, Ph.D., професор, Державний університет штату Нью-Йорк в Потсдамі, США

Інноваційні підходи до оцінювання конкурентоспроможності підприємств

У рамках статті систематизовано аргументи та контраргументи щодо оцінки конкурентоспроможності підприємства. Автори зазначили, що оцінка конкурентоспроможності підприємства є складним багатофакторним завданням, яке зводиться до виявлення найбільш значущих числових показників конкурентоспроможності та їх інтеграції. Встановлено, що при оцінці конкурентоспроможності підприємств застосовуються окремі коефіцієнти для аналізу виробничої діяльності, фінансового стану, ефективності капіталовкладень, тощо. Систематизація наукових напрацювань свідчить про те, що для оцінки конкурентоспроможності підприємств, більшість науковців використовують фінансові показники. Однак, незважаючи на нормальні фінансові показники, низка підприємств опинялися на межі банкрутства та ліквідації. Виходячи із зазначеного 


\section{N., Tyukhtenko, S., Makarenko, N., Oliinyk, E., Portugal. Innovative Approaches to Enterprise Competitiveness Assessment}

вище, головною метою дослідження $€$ аналіз сучасних методологічних підходів до оцінки конкурентоспроможності підприємств, враховуючи показники ефективності використання внутрішніх ресурсів, функціональні аспекти діяльності підприємства та сучасні умови функціонування суб'єкта господарювання на відповідному сегменті ринку. Методологія даного дослідження заснована на методі таксономічного аналізу з додатковим врахуванням питомої ваги впливу кожного з факторів на інтегральний показник конкурентоспроможності підприємства. При визначенні питомої ваги впливу фракторів було враховано експертні думки зовнішніх фахівців у галузі та рівень їх кваліфікаційних компетентностей. Результати розрахунку інтегрального показника конкурентоспроможності досліджуваного підприємства свідчать про суттєве зниження ефективності та конкурентоспроможності протягом 2015-2017 років порівняно до 2014 року. Враховуючи отримані результати, діяльність підприємства зазнала негативного впливу від втрати ринків постачання сировини та збуту продукції внаслідок анексії АР Крим та військових конфліктів на Сході України. При цьому запровадження безвізового режиму із країнами ЄС спричинило зростання коефіцієнту плинності кадрів та мало негативний вплив на ефективність залучення персоналу до виробничого процесу. У ході дослідження автори прийшли до висновку, що існування підприємства можна вважати об'єктивно обґрунтованим у випадку виробництва необхідних для суспільства товарів та використання ресурсів якісно та кількісно визначених суспільством межах. За результатами дослідження рекомендовано виділяти вісім рівнів конкурентоспроможності, враховуючи технологічне та ресурсне забезпечення, для проведення градації конкурентоспроможності підприємств легкої промисловості.

Ключові слова: інновації, інтегральний показник, конкурентоспроможність, менеджмент, трудові ресурси. 